\title{
Managerial levers in cultivating new mental space for business innovation
}

\author{
M. Leibold*, S.C. Voelpel and E.B. Tekie \\ Department of Business Management, University of Stellenbosch, \\ Stellenbosch 7600, Republic of South Africa \\ ml@sun.ac.za
}

Received August 2004

\begin{abstract}
Individuals and organizations have mindsets that reflect how they view themselves and the world around them. Some prominent authors have commented on this phenomenon and its relevance to business innovation. In this article, we refer to these mindsets as 'mental space' and define the latter as the way individuals and organizations perceive markets, products, industries, boundaries, strategies and capabilities.
\end{abstract}

A common mental space is often shared inside an organization and among its stakeholders, concerning how they compete in their industry, strategic group, value chains and chosen markets. This collective 'conventional wisdom' often perpetuates itself and proves to be ineffective when major discontinuous changes take place in the business environment. Incumbent (industry-established) organizations face the challenge of developing or nurturing new mental space that enables faster innovation inside and across traditional boundaries, especially in an era increasingly characterized by the phenomenon of 'open' and 'networked' innovation.

Despite the fact that recent business literature and prominent authors emphasize the importance of creativity and innovation for organizations in a turbulent environment, there seems to be lack of a clear definition and guidelines for cultivating new mental space for such activities and processes. By drawing from the extant strategic management literature and relevant business examples, this article suggests managerial levers for cultivating new mental space to drive organizational innovation to higher and appropriate levels for its proactive sustainability.

*To whom all correspondence should be addressed.

\section{Introduction}

Most organizations share a common mental set of beliefs, views or conventional wisdom about how they compete in their industry, strategic group, value chains and chosen markets. As emphasized by a number of authors, this commonality often compels organizations to benchmark competitors, follow similar strategies and to focus on competing head-to-head with their rivals, or to achieve a unique position or 'fit' with the environment (e.g. Hamel, 1998 \& 2000; Kim \& Mauborgne, 1999b; Christensen \& Overdorf, 2000; Oosthuizen, 2002). The increasing 'discontinuous' change (Tushman \& Anderson, 1986; Christensen, 1997; Christensen \& Raynor, 2003) that takes place in the business environment often destroys the competence of incumbent firms in an industry, requiring them to acquire new skills, abilities and knowledge (Tushman \& Anderson, 1986). In other words, the contention is that traditional sources of competitive advantage alone have become inadequate, opening ways for new entrants and unforeseen competitors previously thought to be in a different line of business (or industry) to impact with innovative and radical business models.

Many organizations and knowledgeable observers now propose, and seem to be experiencing, that strategy innovation - emanating from new (e.g. creatively different, expanded) mindsets - is necessary to break free from direct competition (see Hamel, 2000; Christensen \& Raynor, 2003). The fundamental shift from an internal (closed) innovation perspective to one of 'open innovation' (Chesbrough, 2003), has further underscored the critical importance of innovative, new mindsets (mental space) about how new stakeholder - including customer - value is created, developed and implemented. Open innovation mindsets enable companies to rethink the ways in which they 'view' the fundamental nature of their business, and this requires the cultivation and nurturing of new mental space in the organization. It is by acquiring rapidly-flexible and re-inventive mindsets that organizations not only can cope with the ever-increasing opportunities and threats that arise in the business environment, but proactively create and shape that environment, thus creating unique opportunities and new competitive bases for performance and survival. In this article, we refer to these mindsets of beliefs and views as mental space.

Despite the increasing emphasis on the phenomenon of innovation and reinvention of business models, extant literature shows that there is a lack of understanding of the concept of mental space, as well as managerial levers to cultivate appropriate mental space in business organizations. 
This article describes the nature and importance of mental space for appropriate organizational innovation, and provides frameworks and managerial levers for understanding and cultivating the required types of mental space.

\section{Nature and importance of mental space}

Organizations, as living systems that operate and strive to survive and succeed in a competitive environment, have certain beliefs, views and principles of how they regard themselves and their environment. We refer to these mindsets of views, perceptions, beliefs and values as mental space. Fauconnier (1994) describes mental spaces as providing a medium in which cognitive activities can take place, i.e. the partial cognitive structures that emerge when we think and talk. And it is in these mental spaces that domains are defined, reasoned, changed and merged for purposes of understanding and action. Furthermore, mental spaces are inter-connected and can be modified as thought and discourse unfold (Fauconnier \& Turner, 1998).

For the purpose of this article, mental space could be defined as the images and patterns filling the mind when considering concepts, approaches and practices. Mental space in business, therefore, can be defined as the images and patterns engaging the mind when considering markets, products, industries, boundaries, strategies and capabilities.

The extant disruptive changes in the competitive landscape have mostly rendered conventional business practices and long-established forms of sustainable competitive advantages ineffective (e.g. Hamel, 2000; Tucker, 2001). Incremental innovations that improve the performance of established products and services and that chiefly focus on existing main customers are no longer sufficient in the knowledge era (Christensen, 1997; Kim \& Mauborgne, 1999b; Christensen \& Overdorf, 2000). Restructuring and reengineering processes that improve efficiency should be coupled with disruptive or radical innovation (Hamel, 2000). This involves reinventing one's business model by 'working differently' as opposed to 'working harder' (Prahalad \& Oosterveld, 1999; Hamel, 2000; Prahalad \& Ramaswamy, 2000). Creativity, knowledge and new ideas have become essential in an era where innovative business models enable organizations to keep ahead of competitors (Viscio \& Paternack, 1996; Hamel, 1998 \& 2000; Govindarajan \& Gupta, 2001; Tucker, 2001). Established firms in certain industries have often learnt the hard way that they need to acquire new knowledge and capabilities if they are to survive and to compete with new entrants and unanticipated competitors (e.g., Britannica Encyclopaedia's failure in 'competing' with the CD-ROM).

Numerous scholars have emphasized the importance of business innovation and creating new customer value proposition. Several arguments have been put forward whereby organizations should break out of the conventional 'way of doing business', continuously create new (reinvent) their business models, and deploy different techniques that enable them to encourage innovation and knowledge creation. Table 1 recapitulates major relevant concepts brought forward by prominent authors.

Table 1: Recent business innovation concepts and the underlying rationale of mental space

\begin{tabular}{|c|c|}
\hline Concepts & Underlying Rationale \\
\hline $\begin{array}{l}\text { Changing the rules of the game } \\
\text { (Hamel, 1998) }\end{array}$ & $\begin{array}{l}\text { Shift in thinking about innovation from the traditional product-centric view to that of systemic view of } \\
\text { business model innovation. }\end{array}$ \\
\hline $\begin{array}{l}\text { Concept of ‘Ba’ } \\
\text { (Nonaka \& Konno, 1998) }\end{array}$ & $\begin{array}{l}\text { 'Ba' as a shared space (physical, virtual or mental space) for emerging relationships that serves as a } \\
\text { foundation for knowledge creation and sharing. }\end{array}$ \\
\hline $\begin{array}{l}\text { Dynamic capabilities } \\
\text { (Brown \& Eisenhardt, 1998) }\end{array}$ & $\begin{array}{l}\text { Capabilities that are essential building blocks required to develop a dynamic strategy when competing } \\
\text { at the 'edge of chaos.' }\end{array}$ \\
\hline $\begin{array}{l}\text { Dynamic thinking } \\
\text { (Markides, 1999) }\end{array}$ & $\begin{array}{l}\text { A dynamic process of continuously searching for new strategic positions while competing in current } \\
\text { position, managing both positions simultaneously. }\end{array}$ \\
\hline $\begin{array}{l}\text { New value curves } \\
\text { (Kim \& Mauborgne, 1999a) }\end{array}$ & $\begin{array}{l}\text { Configure offerings to customers by looking across traditional boundaries of competition, thereby } \\
\text { creating new market space. }\end{array}$ \\
\hline $\begin{array}{l}\text { Strategic inflection points } \\
\text { (Grove, 2000) }\end{array}$ & $\begin{array}{l}\text { A point where industry dynamics fundamentally transform due to discontinuous changes, consequently } \\
\text { prompting changes in how business is done. }\end{array}$ \\
\hline $\begin{array}{l}\text { Conceptual road-mapping } \\
\text { (Govindarajan \& Gupta, 2001) }\end{array}$ & $\begin{array}{l}\text { Create new customer value proposition by proactively and constantly creating new and superior } \\
\text { business models. }\end{array}$ \\
\hline $\begin{array}{l}\text { Organizational sense-making } \\
\text { (Weick, 2001) }\end{array}$ & $\begin{array}{l}\text { Realize the limitations of conventional strategies and managerial approaches and focus on making } \\
\text { sense of the complex and discontinuous changes in the environment. }\end{array}$ \\
\hline $\begin{array}{l}\text { Second curve leaps } \\
\text { (Pietersen, 2002) }\end{array}$ & $\begin{array}{l}\text { The time to make critical change is when organizations are still successful and not when they are on the } \\
\text { brink of failing (in this case, a series of continuous reinventing change). }\end{array}$ \\
\hline $\begin{array}{l}\text { Open innovation } \\
\text { (Chesbrough, 2003) }\end{array}$ & $\begin{array}{l}\text { Making the boundary between the firm and the environment more porous, becoming 'open' to the easy } \\
\text { flow of ideas, innovation and knowledge both from inside and outside the organization. }\end{array}$ \\
\hline
\end{tabular}


The concepts in Table 1 are compiled from an analysis of extensively acknowledged authors' viewpoints and maintained aspects on how knowledge and innovation have become essential in business; knowledge's extensive and prevalent nature; and the significance of sharing, creating and utilizing knowledge to anticipate on how to respond to threats and opportunities in the turbulent competitive environment.

With such changes in the competitive environment, individuals' and organizations' mental space have to adjust and become flexible to seize and exploit opportunities that give rise to competitive advantage. The following two sections describe the essential shift from a closed system to one that is open to innovation, knowledge and skills, where organizations rely on both internal and external members who were previously considered to be discrete and isolated from the firm.

\section{Rise of the open enterprise - relying on open innovation}

Offering ‘value innovation’ (Kim \& Mauborgne, 1999b) or having ‘strategic innovation’ (Charitou \& Markides, 2003) means competing in an entirely different way in an existing business by offering fundamentally new and superior buyer value, often enabling the creation of new markets. Similarly, Schumpeter's (1942) concept of 'creative destruction' proposes creating new and superior value that makes existing things and ways of doing things irrelevant. This consists of a fundamental shift in how companies generate new ideas, innovation and knowledge.

It is increasingly observed in the past 10 years that the traditional boundaries of a company have become more permeable, enabling innovation and knowledge to move easily between the firm and its surrounding environment (Nonaka, Reinmoeller \& Senoo, 1998; Chesbrough, 2003; Voelpel, 2003). This is mostly due to the driving forces of technological advancements, globalization and deregulation (e.g. Tapscott, 1997; Kelly, 1998; Evans \& Wurster, 2000). There are advantages that organizations could gain from a closed model, such as increased efficiency and coordination due to reduced transaction costs (Sawhney \& Prandelli, 2000) and heavy internal R\&D and hired 'best' people that enable discovery of great ideas that put the organization in the market first and capture most of the profits (Chesbrough, 2003). However, this closed system will make it difficult for the organization to innovate and renew itself since it does not allow the firm to benefit from the creativity, diversity and flexibility of its various partners. Creating barriers to 'protect' a company from its suppliers and its customers can reduce the variety the firm needs to increase its innovation capability (Sawhney \& Prandelli, 2000). In addition to significantly limiting an organization's opportunity horizon, an inwardly driven firm faces resistance to change from within (Kim \& Mauborgne, 1999b).
An organization that is too focused internally (with a closed innovation approach) is also likely to miss several opportunities since many of these fall outside the organization's current business or will need to be combined with external technologies (or ideas, expertise) to realize their potential. Although in actuality different businesses can be located on a continuum from essentially closed to completely open, the distinguishing characteristic of open innovation is that several approaches to innovation rely on a continued supply of useful ideas and technologies from outside the organization (Chesbrough, 2003). Open innovation is extensively observed in the information technology sector, such as in open-source software development like Linux (Von Krogh, 2003).

Cohen and Levinthal (1990) propose 'absorptive capacity' as the organization's ability to utilize external knowledge to acquire innovative capabilities. They stress that prior knowledge facilitates the assimilation and exploitation of new related knowledge, thereby enabling the organization to recognize the value of new information, assimilate it, and apply it to commercial ends. The prior possession of the relevant knowledge and skill generates creativity, allowing novel combinations and linkages that may not have been considered before (e.g. Kogut \& Zander, 1992). Nonaka and Konno (1998) maintain a similar account that new knowledge emerges through the capture and integration of tacit knowledge (made explicit) with existing knowledge. An increasing means for individuals to share their experiences and mental models seems to be through direct encounters (interactions) enabled by open organizational designs.

As described above, the significance of embracing open innovation strengthens an organization's knowledge and innovation base that is needed to create new customer value. It indicates the development and expansion of organizations' mental views in incorporating outside knowledge and innovation to create new or different value. This is reviewed in the next section.

\section{Evolution of mental views regarding innovation and the enterprise}

Networks have mostly supplanted traditional organizational hierarchies of vertical and horizontal structures. While traditionally focus has been on size, control, role clarity and specialization, in this stage and age in order to survive and compete in the 'new' business environment, organizations need to be adept, fast and flexible by networking and forming relationships with members that are part of the value creating system (Moore, 1993; Ahunja \& Carley, 1999; Ashkenas, 1999; Rouse, 1999). That is, by embracing open innovation, organizations extend far beyond the boundaries of the firm to integrate their ideas, expertise and skills with those outside the organization to discover and deliver novel ways of creating value and to continuously renew themselves (Normann \& Ramirez, 1993; Sawhney \& Prandelli, 2000; Chesbrough, 2003; Von Krogh, 2003). 


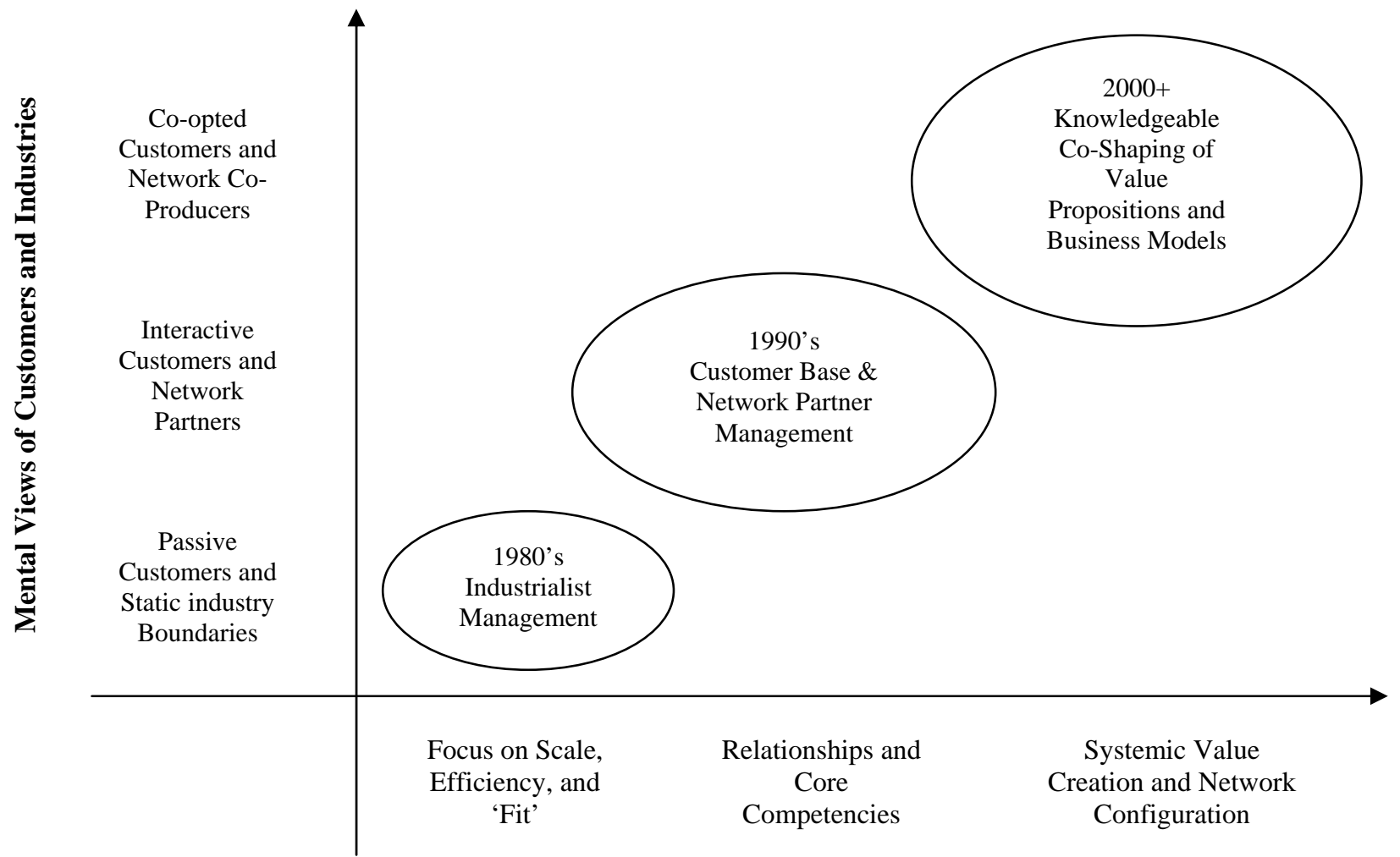

Time and Managerial Focus

Adapted from: Leibold et al. (2002:179).

Figure 1: Evolution of mental views of customers and industries, 1980s to 2000s

The mental views of innovation and the enterprise have dramatically evolved in the last 20 years. Figure 1 illustrates this evolutionary path. In the 1980's, focus mainly was on efficiency and fitting the environment and industry structure (e.g. Ansoff, 1965; Porter 1985). The 1990's brought about establishing interaction with the customer and capitalizing on customer knowledge, as chiefly witnessed in customer relationship management (e.g. Buttle, 1996; Tsokaz \& Saren, 1997). The era from 2000 onwards is characterized with organizations co-shaping value with customers and other stakeholders in a value creating system (e.g. Leibold, Probst \& Gibbert, 2002).

The progression described above indicates the changes in view of the role of the organization from being a valueproviding entity in particular industry value chains merely 'fitting' reactively into value-configurations, to being a coshaping organizer of value creation that may lead to new industry configurations (Leibold, et al., 2002). Figure 1 also illustrates how the position of the customer has evolved from being a passive constituent of the industry to that of a co-producer in a networked community that includes suppliers, partners, competitors and other stakeholders (Prahalad \& Ramaswamy, 2000). This shows that an organization operates and exists in a 'socio-cultural business system' (Leibold et al., 2002) that consists of an economic community of interacting and co-evolving organizations (e.g. suppliers, producers, competitors), individuals (e.g. employees, customers), and other stakeholders (e.g. regulators, society/public).

The diverse knowledge that can be obtained from the various members in the value system can provide a rich source for new information and knowledge. Through direct involvement with customers and other constituents of the value system (and the organization's own internal diverse background) a firm is better able to recognize and exploit new information relevant to the business (Rosenberg, 1982). As a result of the organization developing a broad and active network of internal and external relationships, firms' absorptive capacity is leveraged and strengthened (Cohen \& Levinthal, 1990), increasing the speed, frequency and magnitude of innovation (e.g. Kim \& Kogut, 1996; Helfat, 1997). As networks of relationships develop between organizations, customers and other stakeholders, firms which are well-situated in that network are most likely to form more alliances and are also most likely to innovate (Stuart, 1998).

Therefore, the firm's challenge is not to 'defend' itself from the members of its value network, but how to involve them in its processes of knowledge creation (Sawhney \& Prandelli, 2000). The objective of 'open innovation' is the tapping of knowledge and expertise of individuals both inside and outside the company in conceiving a business model that creates value to customers (Chesbrough, 2003). 
If the organization is to engage with current and potential members of its value network then it should be able to provide many suitable environments for communication to take place (Prahalad \& Ramaswamy, 2000). This involves having to integrate different channels and at the same time being flexible to engage in dialogue with diverse and evolving parties.

Organizations can co-evolve and create new value with other participants in the value network in a number of types of mental space. This is described in the following section.

\section{Types of mental space for business innovation}

There are different types of mental space for strategic innovation. These include market space, industry space, geographic space and capability space. The 'Contrasting Traditional with New Mental Space' column in Table 2 describes the types of mental space and the shift in thinking from the 'traditional' to 'new' mental space.

\section{Market space}

Market space consists of customers and products. Customers are fundamentally changing the dynamics of the marketplace where they are playing an active role in creating and competing for value, becoming part of the enhanced network of the organization that includes suppliers, partners and competitors (Prahalad \& Ramaswamy, 2000). Due to technological advances, customers can access the same information as that of producers/manufacturers, shifting the balance of power from that of makers/sellers of products and services to that of the buyers/users (Davenport \& Klahr, 1998; Prahalad \& Ramaswamy, 2000). Furthermore, consumers are no longer interested in simply buying a product, but also the experience and convenience that goes along with it, such as in the case of electronic banking and online transactions (Prahalad \& Ramaswamy, 2000).

\section{Industry space}

Industry space comprises competitors, the supply chain and value chain. While traditionally competitors were considered to be those that are in the same line of business, forces such as globalization, deregulation and information technology have brought about discontinuities that have resulted in the convergence of industries and the breaking down of traditional boundaries (Viscio \& Paternack, 1996; Tapscott, 1997; Kelly, 1998), thereby reshaping the business landscape and the sources of competitive advantage. As a result, competitors previously deemed irrelevant and unrelated to established business have become either direct or indirect competitors (Tapscott, 1997; Prahalad \& Oosterveld, 1999; Evans \& Wurster, 2000). Furthermore, suppliers have shifted from being distinct and separate entities providing products and services to becoming collaborators and partners in creating and offering value to customers (Inkpen, 1996; Prahalad \& Ramaswamy, 2000).
Similarly, as discussed in the previous section, the value chain has evolved from an industry system to one that crosses a variety of industries, co-evolving cooperatively and collaboratively with others in the business ecosystem (Moore, 1993; Leibold et al., 2002). Therefore, focus has shifted from 'outperforming' the competition to that of coevolving (both in collaboration and competition) with customers, partners, competitors, suppliers, etc. in creating customer value and focusing on 'unique performance' (Moore, 1993; Prahalad \& Ramaswamy, 2000; Leibold et al., 2002).

\section{Geographic space}

Geographic space includes clusters, regions and global space. Clusters have progressed from being internally focused to becoming externally involved with interdependent businesses in linked industries collaborating and competing to attract innovation and investment, as well as enabling technology and knowledge transfer (Porter, 1998). Furthermore, some regions may be inward-looking with high concentration of investment, resources and capital. However, in the knowledge-era they become open to the external environment in order to take advantage of opportunities that might arise and link themselves with various entities in the business ecosystem to exploit these opportunities.

Globalization has been intensifying due to advancements in information technology and deregulation, and has focused on the 'homogenizing' of customer needs. However, the confined perspective of catering for a 'standardized' global market has transformed to that of 'local customizations' in response to cultural and business variations in different parts of the world (Bartlett \& Ghoshal, 1999).

\section{Capability space}

Capability space includes resources, competencies, and dynamics. Due to the shift from an industrial-based to a knowledge- and information-based economy and to gain competitive advantage, organizations are relying more on intellectual (intangible) assets (e.g. knowledge, ideas, skills) and less on the physical (tangible) assets (Sveiby, 1997; Tapscott, 1997; Davenport \& Voelpel, 2001). The building of competencies does not merely consist of training employees and accumulating relevant information, but rather instilling commitment to learning and knowledge creation and sharing to enhance individual and organizational skills and expertise (e.g. Senge, 1992). The dynamics of capability have also shifted from organizations simply becoming adaptive to the changing environment to that of being pro-active, creative and emergent in shaping the external environment (Markides, 1999; Hamel, 2000; Govindarajan \& Gupta, 2001). 
Table 2: Traditional and new types of mental space, and levers to cultivate new mental space

\begin{tabular}{|c|c|c|c|c|c|c|}
\hline \multicolumn{4}{|c|}{ Contrasting Traditional with New Mental Space } & \multicolumn{3}{|c|}{ Levers to Cultivate New Mental Space } \\
\hline \multicolumn{2}{|c|}{ Types of Mental Space } & $\begin{array}{l}\text { Traditional } \\
\text { Perception }\end{array}$ & New Perception & $\begin{array}{l}\text { Types of New } \\
\text { Mental Space }\end{array}$ & Levers/ Techniques & $\begin{array}{l}\text { Business } \\
\text { Examples }\end{array}$ \\
\hline \multirow{6}{*}{ Market space } & \multirow{3}{*}{ Customers } & \multirow{3}{*}{ Invisible } & \multirow{3}{*}{ Visible } & \multirow{3}{*}{$\begin{array}{l}\text { New Customer/ } \\
\text { Market Space }\end{array}$} & $\begin{array}{l}\text { Redefine buyer } \\
\text { groups }\end{array}$ & Philips \\
\hline & & & & & $\begin{array}{l}\text { Apply new data } \\
\text { mining techniques }\end{array}$ & $\begin{array}{l}\text { Starbucks, E- } \\
\text { Bay }\end{array}$ \\
\hline & & & & & Prosumerism & $\begin{array}{l}\text { IKEA, } \\
\text { Quicken }\end{array}$ \\
\hline & \multirow{3}{*}{ Products } & \multirow{3}{*}{ Physical } & \multirow{3}{*}{ Non-physical } & \multirow{3}{*}{$\begin{array}{l}\text { New Product \& } \\
\text { Services Space }\end{array}$} & $\begin{array}{l}\text { Experimentation with } \\
\text { new technologies and } \\
\text { processes }\end{array}$ & Virgin \\
\hline & & & & & $\begin{array}{l}\text { Communities of } \\
\text { Practice (CoP) }\end{array}$ & $\begin{array}{l}\text { Microsoft, } \\
\text { Holcim }\end{array}$ \\
\hline & & & & & $\begin{array}{l}\text { Networked } \\
\text { Incubation }\end{array}$ & $\begin{array}{l}\text { Ford’s } \\
\text { Consumer } \\
\text { Connect }\end{array}$ \\
\hline \multirow{3}{*}{$\begin{array}{l}\text { Industry } \\
\text { space }\end{array}$} & Competitors & Similar & Dissimilar & \multirow{6}{*}{$\begin{array}{l}\text { New Value } \\
\text { Chain Space }\end{array}$} & Deconstruct the & \\
\hline & Supply chain & $\begin{array}{l}\text { Linear, } \\
\text { competitive }\end{array}$ & $\begin{array}{l}\text { Non-linear, } \\
\text { collaborative }\end{array}$ & & $\begin{array}{l}\text { traditional value } \\
\text { chain }\end{array}$ & Dell \\
\hline & Value chain & $\begin{array}{l}\text { Industry } \\
\text { system }\end{array}$ & $\begin{array}{l}\text { Business } \\
\text { ecosystem }\end{array}$ & & $\begin{array}{l}\text { Reconfiguration/ } \\
\text { reintermediation }\end{array}$ & Amazon \\
\hline \multirow{3}{*}{$\begin{array}{l}\text { Geographic } \\
\text { space }\end{array}$} & Clusters & Internal & External & & techniques & \\
\hline & Regions & $\begin{array}{l}\text { Inward, } \\
\text { supportive }\end{array}$ & Open, linked & & \multirow{2}{*}{$\begin{array}{l}\text { Systemic scorecards } \\
\text { (including BSC) }\end{array}$} & \multirow{2}{*}{$\begin{array}{l}\text { BRL Hardy, } \\
\text { Wal-Mart }\end{array}$} \\
\hline & Global & Standardized & $\begin{array}{l}\text { Local, } \\
\text { metanational }\end{array}$ & & & \\
\hline \multirow{3}{*}{$\begin{array}{l}\text { Capability } \\
\text { space }\end{array}$} & Resources & Visible & Invisible & \multirow{3}{*}{$\begin{array}{l}\text { New Capability } \\
\text { Space }\end{array}$} & $\begin{array}{l}\text { Reconstitute core } \\
\text { competencies }\end{array}$ & Disney \\
\hline & Competencies & $\begin{array}{l}\text { Training, } \\
\text { information }\end{array}$ & $\begin{array}{l}\text { Learning, } \\
\text { knowledge }\end{array}$ & & $\begin{array}{l}\text { Disturb existing } \\
\text { processes and } \\
\text { resources }\end{array}$ & Shell \\
\hline & Dynamics & Adaptive & $\begin{array}{l}\text { Creative, } \\
\text { emergent }\end{array}$ & & $\begin{array}{l}\text { Knowledge creation } \\
\text { techniques ('Ba') }\end{array}$ & Skandia \\
\hline
\end{tabular}

\section{Summary}

The types of new mental space described above seem to be essential in creating innovative business models. Creative business models generally consist of four key elements. These are: reinventing the customer base, reinventing customer value proposition, reconfiguring value chains, and reconceiving organizational capabilities (Leibold et al., 2002). In reinventing business models these four elements consider the significance of offering new customer value proposition to a customer base not yet addressed, through a reconfigured value network both inside and outside the organization, facilitated by enabled organizational capabilities. It means developing innovative business models by creating new customer/market space, new products/service space, new systemic value chain space and/or new capability space. These are discussed in the next section. 


\section{Managerial levers to cultivate new mental space}

As described above, in cultivating new mental space, organizations should be able to transcend traditional industry, market, geographic and capability mindsets. Table 2 describes the types of new mental space and their corresponding managerial levers in enabling organizations to create new and competitive business models (see the second column in Table 2, 'Levers to Cultivate New Mental Space'). Each type of new mental space and managerial lever is illustrated by corresponding practical business example(s).

\section{Levers for new customer/market space}

One way of creating new customer base is by redefining buyer groups. This is the uncovering of a hidden customer segment large enough to dramatically expand the industry's total customer base (Govindarajan \& Gupta, 2001). In most industries, companies converge around a common definition of who the target customer is. In actuality, however, it is possible to find new customers/markets by getting out of the conventional mindset of a 'given' customer, market and industry (Christensen, 1997; Kim \& Mauborgne, 1999a). A company that has managed to redefine its buyer group is Philips Lighting Company by introducing an environmentally friendly bulb that, when discarded, reduced the high disposal cost for companies. Philips focused on 'influencers' such as public relations people (concerned about toxic disposal costs), as opposed to purchasers (who based their decisions on light bulb life-span and cost).

Another lever in increasing customer space is applying new data mining techniques. Conventional market research techniques of analyzing customer needs (such as through customer surveys and concept testing) can be complemented through directly involving customers/consumers in an attempt to tap into unrealized or unmet needs and wants, including those unexpressed needs that reside in customers' heads. This involves methods that assist in translating customers' tacit knowledge into readily understandable forms (Nonaka \& Konno, 1998). Firms can assist customers to easily articulate and express their needs and wants by employing user-friendly tools such as computer simulations (Von Hippel, 2001; Thomke \& Von Hippel, 2002). Starbucks and E-Bay have created new customer space by successfully establishing themselves in the espresso-bar business and online auctioning respectively, both strategies previously deemed to be improbable concepts.

An additional technique in developing market space is getting consumers actively involved in the production process. This is known as 'prosumerism' (Toffler, 1980) where the company and its customers 'co-create' products and services. In this case, both rely on the relationship they develop and maintain in creating products and/or services (Wikström, 1996; Kelly, 1998; Sawhney \& Prandelli, 2000). Well-recognized examples of companies that involve consumers in the final product are IKEA in home furnishing and Intuit's Quicken easy-to-use software that allows individuals' to manage their personal finances.

\section{Levers for new product and service space}

To generate fundamentally new products/services, one approach is for organizations to constantly experiment with different ideas and proposals. Continuous experimentation with new technologies and processes provide the flexibility organizations need to operate in the constantly changing and unpredictable business environment. Additionally, experimentation helps organizations to minimize the risks of ultimately ending up with failed strategies. Consequently, firms should not have singular focused strategies, but a multiple 'robust adaptive' strategies that will provide the required flexibility in exploiting new opportunities (Beinhocker, 1999; Markides, 1999). For instance, Virgin is a company that has lucratively experimented in, for e.g., international airlines, health clubs, music recording/retailing and soft drinks.

'Communities of Practice' (CoP) can be used where groups of self-selected people informally bound together across traditional organizational or industry boundaries share their expertise, interests and knowledge (Inkpen, 1996; Sawhney \& Prandelli, 2000; Wenger \& Snyder, 2000). These 'communities' are self-organizing and their life-span is limited with the group dissolving when a given project is completed. Interacting with a common interest to exchange ideas, skills, knowledge and tips, cross-functional individuals, teams, units or organizations are able to define (new) problems and their solutions. Both Microsoft in developing and testing its software and Holcim, the Swissbased global cement producer, make use of CoP to enable solving problems and to share and exchange knowledge.

Likewise, 'networked incubation' fosters partnerships among start-up teams and other firms, thus facilitating the flow of knowledge and talent across companies and the forging of marketing and technology relationships between them. They also network to obtain resources and partner with others quickly, allowing them to establish themselves in the market place ahead of competitors (Hansen, Chesbrough, Nohria \& Sull, 2000). Ford's ConsumerConnect strategy to have an online presence to reach both the consumer and its dealers is a case in point. To accomplish this, Ford partnered with the world's leading technology firms, Microsoft and Trilogy Software.

\section{Levers for new value chain space}

In organizational networks, as reliable information becomes widely available, there is a peer-like relationship among the members of the organization and close relationship is formed between the organization and its customers, suppliers and even competitors (Kelly, 1998). This deconstruction of traditionally integrated value chains offers opportunities for organizations to network and collaborate with others in creating new value propositions (new business models or industries). For example, Dell's 'direct distribution' model consisted of customizing hardware and software according to customers' orders and shipping it to its end users, removing retailers in the process.

Another lever for new value chain space is reconfiguration/reintermediation techniques. With the 
deconstruction of traditional business structures of organizations and value chains, the economy undergoes disintermediation, i.e. companies are able to deal directly with customers and end users (Prahalad \& Oosterveld, 1999). This disintermediation creates opportunities for 'reintermediation' - i.e. with abundant connections between members in a network, the higher the prospect for reconfiguring the value chain, which in turn gives new opportunities for different kinds of intermediaries (Kelly 1998; Tapscott, 1997) - such as 'innomediaries' that connect companies with a variety of current and potential customers over the Internet (Sawhney, Prandelli \& Verona, 2003). For instance, Amazon.com is not only an online book 'retailer' (in addition to selling music CDs, games, toys and hardware) but also offers book reviews and suggests books according to customers' past orders and others' similar order history.

Systemic scorecards (an expanded concept of the BSC) are proposed as measurement techniques for the overall fitness of a socio-cultural business system (Leibold et al., 2002). This means improving not only shareholder but also customer and other stakeholders' value through value networks of collaboration and competition and systemic knowledge management. BRL Hardy in the wine industry and Wal-Mart in discount retailing are examples of organizations that have incorporated the interests of the extended members of the value system (see Leibold et al., 2002).

\section{Levers for new capability space}

In reconstituting core competencies for new capability space, organizations move beyond their traditional boundaries of internal competencies of unique resources and processes and also look for competence in customers and other external entities in the systemic value chain. An example is Disney that pioneered in animated movies and theme parks, creating a broadened family entertainment value.

Another way of increasing new capability space is to stimulate creativity in the organization by 'disturbing' existing processes and resources and by creating 'bounded instability' (Youngblood, 1997). The concept of the 'edge of chaos' maintains that living systems are most flexible and have the greatest potential for novelty and creativity, and 'self-organize' into higher levels of order, when they operate far from equilibrium but have not collapsed into chaos (Pascale, 1999; Youngblood, 1997, 2000). Shell, for example, deposed its resistant bureaucracy and impenetrable culture by putting top management in direct contact with the people at the front-line of the organization and by creating a new sense of urgency.

Knowledge creation techniques can also be used in enhancing capability space. A key point in knowledge creation and sharing is the 'self-transcending' process - i.e. individuals, teams, organizations reaching out beyond their inner- and outer-limited boundaries/perspectives, thus diminishing the barrier between 'self' and 'others' (Nonaka \& Konno, 1998). The knowledge conversion process of socialization, externalization, combination, and internalization (SECI model) is enabled by ' $\mathrm{Ba}$ ' - a shared space which could be physical, virtual, or mental space. The four types of $b a$ (originating $b a$, interacting $b a$, cyber $b a$, and exercising $b a$ ) offer platform for specific steps in the knowledge creation process (Nonaka, et. al, 1998; Nonaka, Toyama, \& Konno, 2000). Skandia, the Swedish insurance company, for example, brings together employees from across its various operating units and countries. The group communicates regularly, constantly building relationship both within and outside the company.

\section{Summary}

Different innovative approaches work differently for different organizations in different industries. The managerial levers/techniques referred to above enhance the four types of new mental space that enable organizations to find new opportunities by adapting to the rapidly changing environment and/or proactively changing it. By taking up these new opportunities, organizations are able to stay one step ahead of competitors (or 'leaping' them) in bringing significantly new value to customers.

\section{Prerequisites for cultivating mental space}

Organizations often experience contentment through a natural tendency of 'getting too comfortable' with a business model that has become initially distinctive and profitable. This is often risky since successful business models get imitated with time and newer and better business models are continuously created by others (Tucker, 2001), thereby creating new markets or capturing the already existing niche from established firms. Companies therefore should be able to develop and manage a family of business models and robust organizational capabilities (both traditional and new). This could be accomplished through, firstly, understanding and managing traditional business model and innovative business models. Changes in industry conditions, evolving customer preferences, and variety of competitors have radically changed the so-called 'traditional' business landscape, making it an unpredictable and uncertain competitive environment (Prahalad \& Oosterveld, 1999; Hamel, 2000). In such turbulent environment, successful companies are those that are able to manage existing, established business models through incremental improvement and at the same time constantly experiment with new, innovative business models (Beinhocker, 1999; Markides, 1999; Pietersen, 2002).

Secondly, organizations should constantly strive to hone their sense-making capabilities in trying to understand the complex business environment. Identifying critical 'turning points,' 'inflection points', or when to take 'large leaps' is not an easy task, but monitoring and recognizing the tell-tale changes in the market/industry is crucial for getting ahead and staying ahead of the competition (Markides, 1999; Weick, 2001). Absorptive capacity of assimilating and exploiting new/external knowledge (Cohen \& Levinthal, 1990) makes the organization more adept in forming its expectations about and becoming sensitive to the nature and trends of emerging technologies, markets, customers and other opportunities (and threats) in the environment. 
Thirdly, organizations can benefit from increased/new customer capabilities. Collaborating with customers in creating value is advantageous both to the customer and the firm, increasing the level of creativity on both sides (Wikström, 1996). But the extent of this gain reaches far beyond to other members in the systemic value chain making the system more focused and directed towards creating new customer value proposition, the basis from which viable and successful business models are developed. In such a 'co-option' process, both the organization and the customer rely on the relationship they develop in creating products/services. The firm should be able to maintain such a relationship by giving recognition and motivation by means of incentives and rewards to encourage ongoing customer participation.

Fourthly, organizations should co-evolve collaboratively and competitively with other members in the business ecosystem in creating new business models, i.e. enhancing their network reconfiguration capabilities. An organization could not exist on its own or have the necessary resources and capabilities to exploit opportunities in the environment. It needs to network and reconfigure itself with partners, suppliers, competitors, customers, employees and other stakeholders in anticipating changes in the environment and in quickly exploiting arising opportunities.

Finally, in a turbulent and unpredictable business environment, the numerous contributing members involved in the value creation process and the process of experimenting with and generating diverse ideas can make an individual firm susceptible to confusion as to who to listen to, which route to take, and what decisions to make. An organization should therefore have appropriate systemic leadership capabilities that can stimulate, cohere, guide, enhance and reward creativity and innovation. Additionally it should have a dynamic, systemic view in measuring the performance of individuals, teams, and communities in business networks.

\section{Conclusion}

The mental views of innovation and the enterprise have significantly changed over the last few decades, with current emphasis on open innovation and open enterprise. The driving forces behind such change have made many conventional business practices seemingly incapable of dealing adequately with the fast changing and unpredictable business environment. To survive and thrive in such a complex landscape, it has become necessary to create new relationships and new mental space with diverse members in the socio-cultural business system that includes employees, partners, suppliers, competitors, and most importantly, customers. The easy flow of knowledge, ideas, skills, expertise among such members increases the sources of competitive advantage whereby organizations can create new value propositions that enable them to capture new strategic positions.

The concept of mental space has been highlighted as the mindset or mental frame (views, perceptions, thinking, values and beliefs) through which individuals and organizations understand the nature of their business. The different types of new mental space described in this article provide pointers for the various areas where business innovation can take place. By overcoming the confinement of traditional industry, market, geographic and capability mindsets, particular managerial levers can assist organizations in cultivating new mental space in proactive response to the constantly changing environment and in disruptive business models that are emerging or necessary. These managerial levers facilitate in expanding and/or creating new customer/market space, product and service space, value chain space and capability space.

Although the significance of the concept of mental space and the above proposed managerial levers in cultivating mental space seem to be evident, further research is necessary to extensively explore and validate the nature and extent of the concept and its suggested managerial levers.

\section{References}

Ahunja, M.K. \& Carley, K.M. 1999. 'Network structure in virtual organizations’, Organization Science, 10(6):741.

Ansoff, H.I. 1965. Corporate strategy. New York: McGrawHill.

Ashkenas, R. 1999. 'Creating the boundaryless organization’, Business Horizons, 42(5): 5-10.

Bartlett, C.A. \& Ghoshal, S. 1999. Transnational management: Text, cases, and readings in cross-border management. $3^{\text {rd }}$ Edition. New York: McGraw-Hill.

Beinhocker, E. 1997. 'Strategy at the edge of chaos', The McKinsey Quarterly, 1:24-39.

Beinhocker, E. 1999. 'Robust adaptive strategies', MIT Sloan Management Review, 40(3):95-106.

Brown, S.L. \& Eisenhardt, K.M. 1998. Competing on the edge: Strategy as structured chaos. Boston: Harvard Business School Press.

Buttle, F. 1996. Relationship marketing: Theory and practice. London: Paul Chapman.

Charitou, C.D. \& Markides, C.C. 2003. 'Responses to disruptive strategic innovation', MIT Sloan Management Review, 44(2):55-63.

Chesbrough, H.W. 2003. 'The era of open innovation', MIT Sloan Management Review, 44(3):35-41.

Christensen, C.M. 1997. The innovator's dilemma - when new technologies cause great firms to fail. Boston: Harvard Business School Press.

Christensen, C.M. \& Overdorf, M. 2000. 'Meeting the challenge of disruptive change', Harvard Business Review, 78(2):66-76. 
Christensen, C.M. \& Raynor, M.E. 2003. The innovator's solution - creating and sustaining successful growth. Boston: Harvard Business School Press.

Cohen, W.M. \& Levinthal, D.A. 1990. 'Absorptive capacity: A new perspective on learning and innovation', Administrative Science Quarterly, 35:128-152.

Davenport, T.H. \& Voelpel, S.C. 2001. 'The rise of knowledge towards attention management', Journal of Knowledge Management, 5:212-221.

Davenport, T.H. \& Klahr, P. 1998. 'Managing customer support knowledge', California Management Review, 40(3):195-208.

Evans, P. \& Wurster, T. 1997. 'Strategy and the new economics of information', Harvard Business Review, 75(5):71-82.

Evans, P. \& Wurster, T. 2000. Blown to bits: How the new economics of information transforms strategy. Boston: Harvard Business School Press.

Fauconnier, G. 1994. Mental spaces. New York: Cambridge University Press.

Fauconnier, G. \& Turner, M. 1998. 'Conceptual integration networks’, Cognitive Science, 22(2):133-187.

Gibbert, M., Leibold, M. \& Probst, G. 2002. 'Five styles of customer knowledge management, and how smart companies use them to create value', European Management Journal, 20: 459-469.

Govindarajan, V. \& Gupta, A. 2001. 'Strategic innovation: A conceptual road map’, Business Horizons, 44(4):3-12.

Grove, A. 1996. Only the paranoid survive. New York: Doubleday.

Hamel, G. 1998. 'The challenge today: Changing the rules of the game', Business Strategy Review, 9(2):19-26.

Hamel, G. 2000. Leading the revolution. Boston: Harvard Business School Press.

Hansen, M.T., Chesbrough, H.W., Nohria, N. \& Sull, D.N. 2000. 'Networked incubators: hothouses of the new economy’, Harvard Business Review, 78(5):74-84.

Helfat, C.E. 1997. 'Know-how and asset complimentarity and dynamic capability accumulation: The case of R\&D', Strategic Management Journal, 18: 339-360.

Inkpen, A.C. 1996. 'Creating knowledge through collaboration', California Management Review, 39(1):123140 .

Kelly, K. 1998. New rules for the new economy: 10 Radical strategies for a connected world. New York: Viking Penguin.
Kim, D.J. \& Kogut, B. 1996. 'Technological platforms and diversifications’, Organization Science, 17: 283-301.

Kim, W.C. \& Mauborgne, R. 1999a. 'Creating new market space’, Harvard Business Review, 77(1): 83-93.

Kim, W.C. \& Mauborgne, R. 1999b. 'Strategy, value innovation, and the knowledge economy', MIT Sloan Management Review, 40(3): 41-54.

Kogut, B. \& Zander, U. 1992. 'Knowledge of the firm, combinative capabilities, and the replication of technology', Organization Science, 3: 383-397.

Leibold, M., Probst, G. \& Gibbert, M. 2002. Strategic management in the knowledge economy: New approaches and business applications. New York: Wiley.

Markides, C.C. 1999. 'A dynamic view of strategy', MIT Sloan Management Review, 40(3): 55-63.

Moore, J.F. 1993. 'Predators and prey: A new ecology of competition’, Harvard Business Review, 71(3): 75-86.

Nonaka, I. \& Konno, N. 1998. 'The concept of 'Ba': Building a foundation for knowledge creation', California Management Review, 40(3): 40-54.

Nonaka, I., Reinmoeller, P. \& Senoo, D. 1998. 'The 'ART' of knowledge: Systems to capitalize on market knowledge', European Management Journal, 16: 673-684.

Nonaka, I., Toyama, R. \& Konno, N. 2000. 'SECI, Ba and leadership: A unified model of dynamic knowledge creation', Long Range Planning, 33: 5-34.

Normann, R. \& Ramirez, R. 1993. 'From value chain to value constellation: Designing interactive strategy', Harvard Business Review, 71(4): 65-77.

Oosthuizen, H. 2002. 'Business strategy and marketing: the positioning versus resource-based dichotomy and the way forward', South African Journal of Business Management, 33(3): 1-16.

Pascale, R.T. 1999. 'Surfing at the edge of chaos', MIT Sloan Management Review, 40(3): 83-94.

Pietersen, W. 2002. Reinventing strategy: Using strategy learning to create and sustain breakthrough performance. New York: Wiley.

Porter, M.E. 1985. Competitive strategy. New York: Free Press.

Porter, M.E. 1998. 'Clusters and the new economics of competition’, Harvard Business Review, 76(6):77-90.

Prahalad, C.K. \& Oosterveld, J.P. 1999. 'Transforming internal governance: The challenge for multinationals', MIT Sloan Management Review, 40(3):31-39. 
Prahalad, C.K. \& Ramaswamy V. 2000. 'Co-opting customer competence', Harvard Business Review, 78(1): 79-87.

Rosenberg, N. 1982. Inside the black box: Technology and economics. New York: Cambridge University Press.

Rouse, W.B. 1999. 'Connectivity, creativity, and chaos', Information Knowledge Systems Management, 1: 117-131.

Sawhney M. \& Prandelli, E. 2000. 'Communities of creation: Innovation in turbulent markets', California Management Review, 42(4): 24-54.

Sawhney, M., Prandelli, E. \& Verona, G. 2003. 'The power of innomediation', MIT Sloan Management Review, 44(2): 77-82.

Schumpeter, J.A. 1942. Capitalism, socialism and democracy. New York: Harper and Row.

Senge, P. 1992. The fifth discipline: The art and practice of the learning organization. London: Century Business.

Stock, G.N., Greis, N.P. \& Fischer, W.A. 2001. 'Absorptive capacity and new product development', Journal of High Technology Management Research, 12: 77-91.

Stuart, T.E. 1998. 'Network positions and propensities to collaborate: An investigation of strategic alliance formation in a high-technology industry', Administrative Science Quarterly, 43: 668-698.

Sveiby, K. 1997. The new organizational wealth: Managing and measuring knowledge-based assets. San Francisco: Berrett-Koehler.

Tapscott, D. 1997. 'Strategy in the new economy', Strategy \& Leadership, 25(6): 8-14.

Thomke, S. \& Von Hippel, E. 2002. 'Customers as innovators: A new way to create value', Harvard Business Review, 80(4):74-81.

Toffler, A. 1980. The third wave. New York: Morrow.

Tsokaz, N. \& Saren, M. 1997. 'Building relationship platforms in consumer markets: A value chain approach’, Journal of Strategy Marketing, 5(2):105-120.

Tucker, R. 2001. 'Strategy innovation takes imagination', Journal of Business Strategy, 22(3):23-27.

Tushman, M.L. \& Anderson, P. 1986. 'Technological discontinuities and organizational environments', Administrative Science Quarterly, 31: 439-465.

Viscio, A. \& Pasternack, B. 1996. 'Toward a new business model', Strategy + Business, $2^{\text {nd }}$ Quarter. [online] URL:http://www.strategy-business.com/press/article/14974.
Voelpel, S.C. 2003. The mobile company: An advanced organizational model for mobilizing knowledge, innovation and value creation. St. Gallen: IFPM.

Von Hippel, E. 2001. 'Perspective: User toolkits for innovation', Journal of Product Innovation Management, 18(4): 247-257.

Von Krogh, G.F. 2003. 'Open-source software development’, MIT Sloan Management Review, 44(3): 1418.

Weick, K.E. 2001. Making sense of the organization. Oxford: Blackwell.

Wenger, E.C. \& Snyder, W.M. 2000. 'Communities of practice: The organizational frontier', Harvard Business Review, 78(1):139-145.

Wikström, S. 1996. 'The customer as co-producer', European Journal of Marketing, 30: 6-19.

Wolpert, J.D. 2002. 'Breaking out of the innovation box', Harvard Business Review, 80(8): 77-83.

Youngblood, M. 1997. 'Leadership at the edge of chaos', Strategy \& Leadership, 25(5): 8-14.

Youngblood, M. 2000. 'Winning cultures for the new economy’, Strategy \& Leadership, 28(6):4-9. 
